日本農薬学会誌 23, 471-478 (1998)

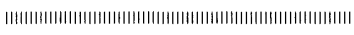
IX ICPC 特別記事

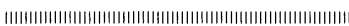

\title{
Topic 7
}

\section{Residues in Food and the Environment}

\section{残留農薬研究所 坂 真智子}

\section{免疫測定法関係の発表について}

免疫は動物が自己と異なる非自己を認識して排除する生命維 持の基本機能である。この免疫の特徵は，その動物個体がもた ない物質が体内に侵入すると，その物質とだけ選択的に結合す る免疫グロブリン（抗体）や活性化される細胞 (リンパ球) が 生じる。この抗体やリンパ球は，生体内はもちろんのこと試験 管内でも動物がもたないその物質と反応する．動物に免疫を与 之る物質は免疫原（抗原）と呼ばれている。抗原とそれに対応 する抗体が結合する反応は極めて特異的なものであり，かなり 低濃度でも反応し, 反応の結果生じた複合体は通常かなり安定 で温和な条件下では容易に解離しないことが知られている。こ の抗原抗体反応を利用した測定法が免疫測定法 (Immunoassay) である. 抗原か抗体の一方を何かで標識する方法であり，醰素， 放射性同位元素, 螢光物質等が報告されているが，今回のポス 夕ー発表においては酵素免疫測定法（ELISA）が主であった。 免疫測定法は，臨床化学分野において多用されてきた分析方法 であるが, 最近では残留農薬分析への適用に関心が高まってい る. 迅速性, 操作性, 経済性等の面から, 多量の試料を対象と するスクリーニング，モニタリングへの適用が望まれている。

Topic 7 に打忛免疫測定法関係のポスター発表の数にもその 関心度の高さが現れていた. 実際の数としては, Subtopic 7Aに おいては 25 題, Subtopic 7Cにおいては 4 題の発表があった.

本来，抗原は高分子（分子量が数千以上）のものであるが, できた抗体が結合相手として認識するのはその一部で低分子の サイズである，ほとんどの農薬は低分子量であるため，免疫反 応を引き起こさせるために高分子量のタンパク質と結合させ， 人工高分子を作ることにより，免疫原と成り得る。一般に抗体 の特異性は人工高分子の場合, 低分子の部位に高く, タンパク 質の部位ではない，また，对象農薬にタンパク質等との結合が 可能となる官能基がない場合，適当な官能基を持つ側鎖を導入 する必要がある(ハプテン合成)。ハプテンの合成やタンパク質 との結合は抗体を産生するうえで重要なポイントの一つであ る. 7A-047 宮本らは Pyridaben のハプテンを計算化学により 6 種選択し, タンパク質 (CONA, BSA and OV) と結合し, 免 疫してポリクローナル抗体を産生し, 酵素免疫測定法を開発し た．実施例は少ないものの，試行錯誤に陥りがちなハプテンの 選択において，有益な手法であると考之られ，注目度も高かっ た.7A-064 Szekacs A.らは Fenoxycarb のハプテンを 3 種合成 し，タンパク質（KLH, CONA and BSA）と結合したものを用 いて，モノクローナル抗体を調製し，ELISA 系を開発した。 7A-061 Pupek K らはAtrazineの新しいハプテンを3 種合成 しより特異的な ELISA 系を開発した。

抗体の種類としては，大別して 2 種類のものがある．免疫原
で動物を免疫すると免疫原の様及な部分を認識する抗体が産生 され，ポリクローナル抗体 $(\mathrm{pAb})$ と呼ばれている. 免疫した動 物の脾㵴を摘出して, その細胞をミエローマ細胞（癌細胞）と 融合し，それぞれの抗体を産生する細胞をクローン化し，個々 の抗体を得ることができ，これはモノクローナル抗体 $(\mathrm{mAb})$ と呼ばれている.さらに，モノクローナル抗体の調製・生産法 としては, 先に述べた一度樹立したハイブリドーマをマウスの 腹腔に注射し, 腹水ガンマウスを作り,その腹水からモノクロー ナル抗体を得るハイブリドーマ法が一般的である（ハイブリ ドーマは試験管内で培養することも可能である). 一方, 大腸菌 を用いるファージ・ディスプレイ法というものも最近利用され てきている.この方法の一例を挙げると, モノクローナル抗体 の $\mathrm{F}_{\mathrm{V}}$ 領域をコードする遺伝子, $\mathrm{V}_{\mathrm{H}}$ と $\mathrm{V}_{\mathrm{L}}$ を適当なリンカーで 連結させ，一本鎖 $\mathrm{F}_{\mathrm{v}}$ 断片 (single-chain $\mathrm{F}_{\mathrm{v}}$ fragment, $\mathrm{S}_{\mathrm{C}} \mathrm{F}_{\mathrm{V}}$ ) の 遺伝子を構築した後, 遺伝子をファージミドにクローニングし, このファージミドを大腸菌に導入する. その後, この大腸菌に M13へルパー・ファージを感染させ, リコンビナント・ファー ジを作製する．目的の抗原を結合させたマイクロタイタープ レートに加え，プレートを洗浄する (パンニング).このとき， 目的の抗原に対して結合能を持たない抗体を発現している ファージは洗い流され，プレートに結合しているファージは目 的の抗原に対しての抗体を提示している。これを大腸菌に感染 させることにより, リコンビナント抗体 $\mathrm{S}_{\mathrm{C}} \mathrm{F}_{\mathrm{v}}$ をファージ提示 型抗体として生産できる.7A-053 Tout N. L.らは Picloram と Diflubenzuronについて Fab, $\mathrm{S}_{\mathrm{c}} \mathrm{F}_{\mathrm{v}}$ を構築し, リコンビナント抗 体を生産し, 親 $\mathrm{mAb}$ との比較を ELISA 系で実施した. $7 \mathrm{~A}-060$ Pupek K.らは Parathion と Chlorpyrifosについて 2 種の $\mathrm{S}_{\mathrm{c}} \mathrm{F}_{\mathrm{V}}$ を構筑し, リコンビナント抗体を生産し, 測定系を開発し親 $\mathrm{mAb}$ との比較を行った. Parathionにおいて, 双方は類似した 検量線を示した. $\mathrm{S}_{\mathrm{c}} \mathrm{F}_{\mathrm{v}}$ と mAbで LOD $1.6 \mathrm{ng} /$ well と $2.3 \mathrm{ng} /$ well, $\mathrm{IC}_{50} 2.3 \mathrm{ng} /$ well と $11.6 \mathrm{ng} /$ well であった. Chlorpyrifosに ついては $\mathrm{S}_{\mathrm{C}} \mathrm{F}_{\mathrm{v}}$ の方が約 10 倍高い感度を示した. 7A-077 Charlton K. A. らは Atrazine, Simazine と Propazine について $\mathrm{S}_{\mathrm{c}} \mathrm{F}_{\mathrm{V}}$ を構築し, リコンビナント抗体を生産し, 親 mAb での ELISA と比較して 5 10 倍感度の高い測定系を開発した. どの発表に おいても市販のリコンビナント・ファージシステムを使用して おり，それは八イブリドーマ法に比べて作業工程が短く, 操作 も容易である等利点が多く, 今後広く利用されていく可能性が 高い。

測定系の活用法として, 自動化, 免疫センサ一, 簡易検出法 (フィルターの使用) 等の開発が取り上げられていた。7A-050 Wengatz I.らは抗体をセンサーチップ（プラチ十電極）に Polypyrroleを用いて固定化し，抗原が結合することによって周期的 脈動波形の変化を検知することによって抗原を定量的に検出す る電気化学センサーおよびセンサーシステム（フローインジェ クション)を開発し，ELISA 系で測定したデータとの比較を実 
施し，良好な結果が示されていた。7A-054 Baumann R. A. ら は Flow Injection Immunoaffinity analysis (FIIAA)を構築した. Atrazine では $0.1 \mu \mathrm{g} / l$ の測定が可能であった. 地表水と地下水 を実際に測定し，GC-NPD で測定した結果との比較も実施し た.この発表は, the European Program Lifeのプロジェクト (LIFE 95ENV/D/13) の一部である.7A-048 Lukin Y.らは多 孔性メンブラン（膜）に抗原を付着させ，ビオチン化抗体，又 トレプタビジンーペルオキシダーゼ，基質を順次滴下し，発色 の様子で 2,4-D, Atrazine を検出した(Dot-Immunoassay). 発色 しなかった場合， $2,4-\mathrm{D}$ は $2.0 \mu \mathrm{g} / \mathrm{l}$ 以上の濃度であることを示 す。反応時間は非常に短く 5 分程度である。 マイクロタイター プレートを用いた ELISA 系，螢光イムノアッセイとの比較を 2.4-D で実施し，良い相関を示していた。 7A-055 Dzantiev B. D. らは水溶性 Polyelectrolytes を用いて, Simazine に対する二つの 新しい測定系 (ELISA, Dot-Immunoassay) を開発し，水，ミル クおよびジュースに適用した。この発表はCRDFの Award No. RN1-426の一部として公表されたものである.

免疫測定法は一般的にその感度・特異性により, 数多くの物 質が混在する試料であっても，目的の抗原や抗体を単離するこ となく測定することができる、しかしながら，マトリックスの 影響を受けたり，感度が充分でない場合もある。7A-063 坂らは Fenpyroximateに対する ELISA 系を開発し, 作物試料への適用 の際に, 固相抽出ミニカラム $\left(\mathrm{C}_{18}+\mathrm{PSA}, \mathrm{C}_{18}+\mathrm{SAX}+\mathrm{PSA}\right)$ に よる精製を検討し，有効な手法であることを示した。7A-067 Tessier D.M.らは Alachlor の代謝物 CDA 等に対し ELISA 系 を開発し，LODはCDA で $0.05 \mathrm{mg} / l$ であったささらに，水試 料の微量分析を実現するために, 固相抽出ミニカラム $\left(\right.$ Oasis $^{\mathrm{TM}}$ HLB) を採用し, $500 \mathrm{ml}$ の水試料を 1000 倍濃縮し, LOD $10 \mathrm{ng} /$ $l$ を実現した. 7A-052 Eremin S. A.らはDDT, Endsulfan, Myclobutanil, Fenoxycarb, Propanil, Mecoprop, 2, 4, 5-T その他 に対して螢光免度測定法（Fluoroimmunoassay）を開発し，B/ $\mathrm{F}$ 分離を必要とせず，単一試薬の使用でより簡易な方法を提示 した.

モニタリングや一次スクリーニング法としての免疫測定法へ の期待は大きいが，現状としては，食品や作物試料への適用は 未だ少なく, Subtopic 7Bにおいては免疫測定法を採用したもの はなかった. Subtopic 7A, 7C においては, 水および土壌試料へ の適用が多かった. 7A-051 Van Emon J. M.らは尿中の Clorpyrifos 暴露の biomarker としての TCPに対するスクリーニング 法としてELISA 系を開発した。 LOD $3.0 \mathrm{ppb}$ である。7A-056 Willetts C.らは除草剂 ZA1296に対して pAb を産生し，水試料 のスクリーニング法として ELISA 系を開発した. $\mathrm{IC}_{50} 0.1 \mathrm{ppb}$, LOD 0.05 ppbである. 7A-057 Bonwick G. A. らは蚊帳上の Pyrethroid の残留を Permethrin $の$ phenoxyphenyl 部分と交差 する anti-PBA 抗体を用いて ELISA と GC/NCI-MS とで分析 し比較した. 7A-059 Kang J.S. らは Beomacil に対する mAbを 調製し，環境モニタリング法として ELISA 系を開発した。7A062 Hassink J. らは Isoproturon に対する pAb を産生し, スク リーニング法としての ELISA 系を開発した。温室中に水系の microcosm system を構築し, ${ }^{14} \mathrm{C}$-Isoproturon を散布し，その spray-drift や run-off を ELISA と radio-HPLCによって測定し た.その結果はよく一致した. 7A-065 Wang S.らは Benzyl- phenylurea に対しての pAb を産生し, Class-Specific ELISA を 開発し, 土壤, 水試料に適用した. $\mathrm{IC}_{50}$ は Diflubenzuron $0.6 \mathrm{ppb}$, Teflubenzuron $5 \mathrm{ppb}$, Flufenoxuron $10 \mathrm{ppb}$, Lufenuron $31 \mathrm{ppb}$, Chlorfluazuron $45 \mathrm{ppb}$, LOD は 0.05 2.3 ppbである. 7A-066 Schutz S. らは Azadirachtin A に対する pAbを産生し，モニ夕 リング，スクリーニング法として ELISA 系を開発した. $\mathrm{IC}_{50}$ $100 \mathrm{ppb}$ で, 10〜1000 ppbの測定が可能である. 7C-009 Strahan J. らはスルホニルウレア系除草剂 (Metsulfuron methyl, Chlorsulfuron）に対するELISA 系を開発し，水および土壌（24 種） 試料に適用し, LOQ 0.05 ppb を実現した. その他として, Bound Residue を検出する方法として ELISA 系を採用している発表 があった. 7A-023 Jahn C.らは植物の上皮における TPN の光分 解物 (Bound Residue) を測定するために, mAbを調製し, ELISA 系を開発した.7A-049 Harreus D.らは Sandwich-ELISA を開発し, 土壤, 水試料中の Analyzing Bound Residue を測定 した。

抗原抗体反応の特異性を検出法としてだけでなく, 分離法と して利用する方法がある. Immuno Affinity Chromatography で ある. 7A-068 Ballesteros C. らは Fipronil とその代謝物（4 種） の作物残留分析における精製方法として抗体をコーティングし たカートリッジを準備し, 水でコンディショニングした後, 検 液を流下し目的物質を保持させ, 水を流下して洗浄後, メ夕ノ一 ルで溶出し GC-ECD で定量した. 4 作物試料における回収率の 結果は，Fipronil と代謝物（3種）では72１08\%，代謝物 (RPA200766) では 30〜64\%であった. 7A-058 Kang S. J. らは Atrazine に対する $\mathrm{mAb}$ を調製し, ELISA 系を開発した後, affigel と抗体を組み合わせて Immunoaffinity Column (IC)を作り, 環境モニタリングのためにIC-ELISA system を開発した.

各種測定系の開発の目的・背景としては，ヨーロッパにおい ては水の基準值が単成分で $<0.1 \mu \mathrm{g} / l$, 総量で $<0.5 \mu \mathrm{g} / l$ である ことが大きな開発の理由となっている. その規制に対応した分 析をしていくためには,かなりの費用と時間を必要とするため, より安く，迅速に分析できる方法が望まれている。それは新規 剂の開発においても, 登録の際の膨大な量のデ一夕収集に必要 とされている，市場調査, 輸出・入などにも同様の理由で適用 が期待されている. Subtopic 7AのDiscussionにおいては, 発 展途上国などにおいては, 高価な分析装置 (LC/MS/MS 等) を 購入設置し，それを維持管理していくことは難しく，ELISA キットに対する関心が高かった. ELISAの研究は発展段階にあ ク，一度の分析で多くの化合物を検出する（マルチ分析）こと は可能ではない（属を対象とする場合を除く）という久点はあ るものの, 多くの利点を有していることを考えると, 近い将来, 何らかの形での実用化, 公定法への採用が望まれていることが, 発表全体から感じ取れた。より多くの農薬に対する安定した測 定系が開発され，利用価值が高まることを期待したい。

\section{参考資料}

酵素免疫測定法 第 3 版 編集: 石川 栄治, 河合 忠, 宮井 潔 (医学書院)

イムノアッセイによる薬物濃度測定マニュアル（侏テクノ） 免疫学実験入門 生物化学実験法 15 松橋 直, 成田 秀雄, 臼 井 美津子 著 (学会出版センター)

単クーロン抗体実験マニュアル 富山 朔二, 安藤 民衛 編(講 談社サイエンティフィック) 
化学と生物 Vol. 34, No. 4, 1996 「解説 モノクローナル抗体の 利用の現状 井上 國世」

日曹分折センター 時枝 正則

\section{A Advances in Analytical Methodology \& Detection Tech- niques}

このセクションでは 80 題弱の発表がなされた. その内容は大 別して残留分析を構成する試料調製・抽出・精製・定量の各工程 における研究成果であった。これらの研究の方向性をまとめて みると, 試料量, 溶媒量を減少化し, 同定力, 安定性に優れ高 感度で且つ短時間，低コストですむ分析法の確立にあると感じ られた。中でも LC(GC)/MS/MS と ELISA に関する発表が圧 倒的な割合を占めていた．以下に招待講演で本セクションと最 も係りの深いDr. V. Bornemannの講演内容の概略と筆者が興 味を持った発表内容の概略をいくつかのグループに分けて紹介 する。

\section{1. 招待講演}

Advance in Pesticide Residue Methodology V. Bornemann (BASF, Germany, S7.2)

残留分析法の確立は, Maximum Residue Level (MRL) の決 定や risk assessment, tolerance enforcement 及び monitoring program の実施に不可欠である。氏は残留分析技術の進歩を定 量機器の進歩のみからとらえるだけでなく, 試料調製 (GLP electric notebook), 抽出 (SFE, Microwave, Accelerated Solvent Extraction (ASE)?), 定量機器·装置 (GC/MS/MS, LC/MS , Capillary Zone Electrophoresis (CZE), ELISA) 全般について 講演した。特に Limit of Quntitation (LOQ)（日本の検出限界 とは異なる）の低レベル化への対応として定量方法の流れは 「hyphenated techniques in MS instrumentation」にあるとし, これらの機器の長所・欠点に別けて講演した. MS/MS は精製工 程の減少化, 誘導化の不要, 高い同定性·感度, 幅広い化合物へ の応用可などが利点であるが, 反面高い熟練を要し, 結合する 機器によっては未だ分析機器としては十分ではなく（例：CZE では HPLC より感度低く, MS との組合せではまだ初期段階で ある. GCでは誘導化が必要な時もある. LC/MS/MS が一番進 歩は早い.), 普及度及び認可度共に今のところ十分ではないと した.

\section{MS/MS による分析}

MS/MS 分析の中で最も進歩の早いものは LC/MS/MS であ
ク，その研究成果が紹介された。

W. M. Leimkuehler (Bayer Corp. U.S.A. 7A-006)らは土猿, 地下水における FOE5043 (除草剂) 及びその代謝物の分析を紹 介した。 これらは Soil dissipation study, lysimeter studyの一環 として行われた。 土堙 $(10 \mathrm{~g})$ は $20 \mathrm{ml} の 0.1 \mathrm{~N} \mathrm{HCl} / \mathrm{ACN}(1$ : 1)で振とう抽出, 遠心分離され, 得られた上澄み液に内標とし てそれぞれの同位体を添加後濃縮し, LC-API/MS/MS で測定 する. 水試料は酸性化後 $\mathrm{C}_{18}(\mathrm{SPE})$ 処理し, 濃縮して同様に分析 する方法である. 親化合物とそのアルコール体は Positive mode で, Oxalate, Sulfuric acid 及び Thiadone は Negative mode で 測定していた. 水及び土堙の LOQ はそれぞれ $0.1 \mathrm{ppb}$ 及び 10<smiles>Nn1nc(C(F)(F)F)sc1=O</smiles>

FOE Thiadone $\mathrm{m} / \mathrm{z} 168.9 \longrightarrow \mathrm{m} / \mathrm{z} 112.9$<smiles>CC(C)N(C(=O)CS(=O)(=O)O)c1ccc(F)cc1</smiles>

FOE Sulfonic Acid $\mathrm{m} / \mathrm{z} 273.9 \longrightarrow \mathrm{m} / \mathrm{z} 120.9$<smiles>CC(C)N(C(=O)C(=O)O)c1ccc(F)cc1</smiles>

FOE Oxalate $\mathrm{m} / \mathrm{z} 223.9 \longrightarrow \mathrm{m} / \mathrm{z} 151.9$<smiles></smiles>

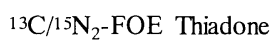
$\mathrm{m} / \mathrm{z} 171.9 \longrightarrow \mathrm{m} / \mathrm{z} 112.9$
Fig. 1 Negative mode analytes ポスターそのものの別刷りから転写.<smiles>CC(C)N(C(=O)CO)c1ccc(F)cc1</smiles>

FOE Alcohol $\mathrm{m} / \mathrm{z} 212.9 \longrightarrow \mathrm{m} / \mathrm{z} 169.9$<smiles>CC(C)N(C(=O)COc1nnc(C(F)(F)F)s1)c1ccc(F)cc1</smiles>

FOE 5043 $\mathrm{m} / \mathrm{z} 364.0 \longrightarrow \mathrm{m} / \mathrm{z} 193.9$<smiles>[2H]C([2H])(C(=O)N(C(=O)CO)c1ccc(F)cc1)C(F)(F)F</smiles>

$\mathrm{d}_{7}$-FOE Alcohol $\mathrm{m} / \mathrm{z} 219.0 \longrightarrow \mathrm{m} / \mathrm{z} 170.9$<smiles>O=C(O)C(=O)C(C(=O)C(F)(F)F)c1ccc(F)cc1</smiles>

$\mathrm{d}_{7}$-FOE Oxalate $\mathrm{m} / \mathrm{z} 230.9 \longrightarrow \mathrm{m} / \mathrm{z} 158.9$
$\mathrm{d}_{7}$-FOE Sulfonic Acid $\mathrm{m} / \mathrm{z} 280.9 \longrightarrow \mathrm{m} / \mathrm{z} 120.9$

Fig. 2 Positive mode analytes ポスターそのものの別刷りから転写. 
ppbで，回収率はいづれも 80〜105\%，バラツキも少なかった (Fig. 1, 2).

Leimkuehler 氏らは Fenamiphos 及び Imidacloprid（いづれ も殺虫剂）の水の分析（7A-009）もほぼ同様の手法で実施して いた。

Earl (Zeneca, UK, 7A-015) らも土壌中の Azoxystrobin（殺 菌剂) 及びその四つの代謝物の残留分析法を LC/MS/MS (multiple reaction monitoring mode：MRM）で確立した. 分析操作

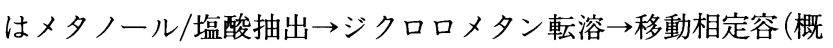
略）といたって簡単であり，親化合物も含めた 5 化合物の HPLCによる分析時間は 5 分以内であった。また試料調製にロ ボットも用いることにより 2 倍以上分析スピードが増加した. LOQ は 0.01 0.02 ppm, 回収率は 0.01, 0.1, $0.5 \mathrm{ppm}$ でいずれの 化合物も 80\%以上であった，GC を使用する時には Compound 28, Compound 30 はそれぞれアルシル化/シリル化剂(?)及び $\mathrm{CH}_{2} \mathrm{~N}_{2}$ による誘導化が必要であった (Fig. 3).

Goller (ADME Bioanalyses, France, 7A-028) らは Etofenprox (殺虫剤) のキャベツにおける残留分析を GC 法から GC/MS/ MS 法に切替えることにより分析時間を短縮した。即ち従来の GC 法に比べて液々分配の工程数を減らし，更にハロゲン誘導 体化を省略することが出来た．以下に GC/MS/MS 分析の機構 を示す. 因みに LOQ は $0.01 \mathrm{ppm}$, 添加回収率は80〜 100\% $(0.01$, $0.1,1 \mathrm{ppm})$ であり，検量線の直線性は $r^{2}>0.99$ であった（Fig，<smiles>CO/C=C(/C(=O)O)c1ccccc1Oc1cc(Oc2ccccc2C#N)ncn1</smiles><smiles>CO/C=C(/C(=O)O)c1ccccc1Oc1cc(Oc2ccccc2C#N)ncn1</smiles><smiles>CO/C=C(/C(=O)OC)c1ccccc1Oc1cc(Oc2ccccc2C#N)ncn1</smiles><smiles>N#Cc1ccccc1Oc1cc(O)ncn1</smiles><smiles>N#Cc1ccccc1Oc1cc(Oc2ccccc2C(=O)O)ncn1</smiles>

Fig. 3 Azoxystrobin 及びその代謝物 講演要旨集より転写.<smiles>[X][R20]N=C(O)c1ccc(Oc2ccc(COCC(C)(C)c3ccc(OCC)cc3)cc2)cc1</smiles>

4). GC-MS 分析については7A-078にも紹介されているが, MS に GC を結合する際は GC の宿命とも言える感度変動への対 応が必要である (一例として Control Matrix を利用しての検量 線作成がなされていた)。

MS/MSによる分析例は 7B, 7C 等のセクションにも多数紹 介されていた（例：T. J. Mayers et al., U.S.A. 7B-013‥作物/動 物臟器).

\section{3. 抽出関係}

いかに効率良く農薬及びその関連化合物を分析対象マトリッ クスから抽出するかは残留分析にとって試料調製と共に第一義 的なものとして重要である．近年その抽出法として Supercritical Fluid Extraction (SFE), Microwave (MW)及び Accelerated Solvent Extraction (ASE)が注目されている.

Wright (Pacific Northwest Division, Richland, U.S.A. 7A043) らは土㙵/砂の含有率を変化させて農薬の回収率を SFEで 調べた. Modifierにメタノールとアセトニトリルを用いていた が全体としてはメタノールの方が良好であった，回収率は50〜 95\%であった. 本報告では作物の結果は報告されていなかった.

Moye (University of Florida, U.S.A. 7A-042) らは Tebuconazole（殺菌剂）を用いて MW 法により抽出を試みた（水温 200 ${ }^{\circ} \mathrm{C}$, 圧力 $\left.190 \mathrm{PSI}\right)$. てん菜の葉部及び根部を用いて USEPA 承認 の従来法である, 常温でアセトン/水 (3:1) を用いての方法と 比較して同等の結果を得た。 そこで MW 法に用いる溶媒を水か らアセトン/水 $(3: 1)$ に変え, 段階的に温度. 圧力を変化させ た結果, 葉部に関してはUSEPA 法より 2 倍高い回収率を得た (根部は変化なし). 抽出効率向上の一つの要因は MW の power 向上 $\left(1000 \mathrm{~W} / 200^{\circ} \mathrm{C}\right.$ まで可) が大きな要因であると結論づけて いた (Fig. 5).ASE（7A-034）の発表にも注目したが発表中止 であった，要旨集に依れば通常抽出法・ソクスレー抽出・超音波 抽出等との比較がなされ, 抽出率はそれらと同等か農薬又はマ トリックス (?) によっては他の抽出法より良好な結果が得られ たと結論づけている.

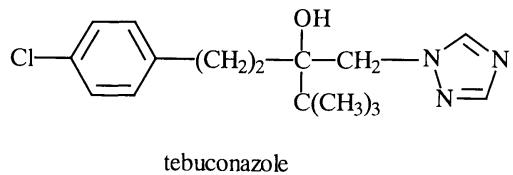

Fig. 5 Tebuconazole

最新農薬データブック (ソフトサイエンス社：1997)より。

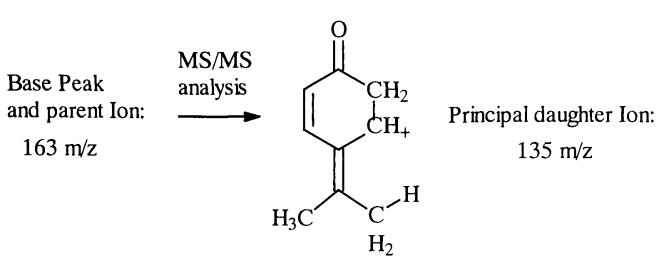

Fig. 4 Etofenprox とその MS/MS 分析の機構

ポスターそのものの別刷りから転写. 


\section{4. 光の他}

Lee (Du Pont, U.S.A., 7A-018) らは Famoxadone（殺菌剂） の作物, 加工品, 土壌の残留分析法を LC/MS, HPLC (UV) 及び GC (NPD) の 3 種類で確立していた。これは全世界にお ける本薬剤の展開及び登録を支えるために必要と説明してい た. LC-MSによる分析操作はカラム精製が不用で他の二つの方 法よりも分析操作が簡単であった. LOQは 0.02 0.05 ppm で あり，LOQ 設定の目安は $\mathrm{S} / \mathrm{N}=4$ ということであった， GC 法 は enforcement method として開発され, USA, 欧州, 南ア及び 日本で validation が実施されたとのことであった。

Ohlin (National Food Administration, Sweden, 7A-030) ら はメチルブロマイド及び2-chloroethanol の Screening method として HS-GC（ECD）が有効であると報告していた.

\section{7B Residue Levels in Foodstuffs \\ 7C Residue Levels in the Environment \\ 7E Trade Issues Concerning Residues}

以上の三つのセクションから試料量の減少化とモニタリング 及びその他の報告についてそれぞれ数例を紹介する.

\section{1. 試料量関係}

Allmendinger (Bayer, Germany, 7B-019) らは残留分析に用い る試料量をどの程度まで減少出来るかをりんご, トマト，ぶど う, 米を用いて検討した. 通常 25〜 $100 \mathrm{~g}$ 用いていた試料量に対 して 2, 5, 10, $20 \mathrm{~g}$ に分けて検討し， $5 \mathrm{~g}$ までは減少化出来ると した $(\mathrm{cv}: 1 \sim 12 \%, n=5)$.トマトに関しては $2 \mathrm{~g} て ゙ も \mathrm{cv} は 10.5 \%$ $(n=5)$ と良好であった。 また試料量 $100 \mathrm{~g}$ と $5 \mathrm{~g}$ の時（それぞ れ $n=10)$ の使用溶媒量 $(S)$ と分析時間 $(T)$ の検討も行い, $5 \mathrm{~g}$ 時を 1 とすると $100 \mathrm{~g}$ 時は $S=4 \sim 10, T \fallingdotseq 2$ であった.

Tadeo (CIT-INIA, Spain, 7C-003) らは Simazine, Thiazopyr, Pendimethalin 及び Hexazione の四つの除草剂を用いた土壌の 残留分析を試料量 $20 \mathrm{~g}$ と $5 \mathrm{~g}$ で分析し, 分析值の比較を行った. 抽出は $20 \mathrm{~g}$ の時は通常の Mechanical shaker を用い, $5 \mathrm{~g}$ の時は プラスティックカラムに入れ超音波抽出を行った。抽出溶媒は いずれも酢酸エチル及びメタノール/水系またはアセトン/水系 であった. $5 \mathrm{~g}$ 使用における添加回収率は従来法と大差なく $80 \%$ 以上であり, 残留分析結果はいづれの農薬についてもほぼ一致 していた。抽出工程での時間も大幅に短縮されていた。

\section{2. モニタリング関係}

Andersson (National Food Administration, Sweden, 7B-023) らはスウェーデンにおける残留農薬モニタリングの結果を報告 していた. 1994〜1997に約 21800 の試料（176 commodity で， それらは 88 力国からのものであった. 国別ではスウェーデン産 は44\%）について分析した。 その結果 cereal grain（穀物）では 約 $84 \%$ の試料からは検出されなかったが約 $15 \%$ の試料からは検 出され，1.3\%の試料では MRL を上回った。これは 1990〜1993 の $2.1 \%$ に比べると減少した. 他方, 果樹·野菜では 40\%の試料か ら検出され，かつ 3.5\%の試料では MRL を上回り，1990１993 の $2.7 \%$ と比べて増加した. 検出された農薬の種類は 1990～1993 調査と 1994〜1999 調査において大差なかった.

Cusick (California Department of Food and Agriculture,
U.S.A., 7E-006) らは(1) Randam Pesticide Residue Monitoring in Food Stuff (一般のモニタリング), (2) Priority Pesticide Monitoring (特定の目的をもったモニタリング) 及び(3) Investigation Analysis (誤使用) の三つの目的に従ってモニタリング を実施した. (1)については Multi Pesticide Residue Method $(\mathrm{MRM})$ を用いて果物及び野菜中の有機リン剂, 有機塩素剂, カーバメート農薬及び 230 種の農薬について分析した. tolerance limit を超えたものは約 1.6\%であった. (分析数 約 5500). (2)に関しては 22 農薬と 43 の commodity の種々の組合わせで 分析しその分析数は 2158 にのぼった。これらは農薬の dietary risk assessment に用いるものである. 因みに tolerance limit を超

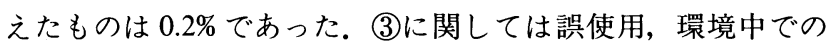
$\mathrm{drift}$, 污染等について調査し, 分析試料は T-シャツから土培, 植物の葉と多種にわたり分析数は 1995 年で 2000 を超した. 更 にカリフォルニアでは, 農産物及び加工品について分析し, そ の分析值が輸入国の MRLsに対して受け入れが可能か否かも 評価している. 分析対象物は有機リン剂, 有機塩素剂, カーバ メント剂, 燻蒸剂, ポストハーベスト殺菌剂, 重金属及び微生 物であり輸入国の MRL に適合しないものは自動的に除去され る.

\section{3. 光 の 他}

調理, 加工が残留化合物にどの様な影響（変化）を与えるか という研究 (R. Mackenzie et al., Pesticide Safety Directorate, $\mathrm{UK}, 7 \mathrm{~B}-042)$ や残留分析のデー夕の質の向上は試料のサンプリ ング方法の部分にまだ余地が残っているとした講演並びに発表 (A. Ambrus, Plant Health and Soil Conservation Station, Budapest, Hungary, S7.1 及び 7E-001）が興味深く有意義であった.

\section{（財）残留農薬研究所 小田中 芳次}

\section{概 要}

Residues (Topic 7)に関する研究成果は以下に示す五つの Subtopicsに区分して発表された.

A. Advances in analytical methodology \& detection techniques $(78)^{*}$

B. Residue levels in foodstuffs (50)*

C. Residue levels in the environment (49)*

D. Residue analysis in developing countries (19)*

E. Trade issues concerning residues $(12)^{*}$ 
*（）内の数は要旨集から求めた発表数で, 実際の発表数 とは異なっている.

A では, 比較的新しい分析機器や分析手法に関する報告とし て, LC/MS/MS, CE (キャピラリ一電気泳動), ASE (加熱溶 媒抽出), MAE (マイクロウエーブ抽出), SPE (固相抽出), SPME (マイクロ固相抽出), 多成分同時分析法, 新規化合物の 分析法, 免疫化学的測定法などの発表があった. Bでは, 作物や 食品残留に係わる報告として, 個別分析法及び多成分分析法, 残留実態 (モニタリング), 登録用の残留試験, 洗浄・調理・加 工，分析試料量の検討などの発表があった，Cでは, 環境に係 わる残留や動態に関する報告として,モニタリング用の分析法, 残留実態(モニタリング), 土壌中での挙動や大気への移行, 土 㙵採取方法, リスク評価などの発表があった。 D では, 発展途 上国の残留問題に係わる報告として，各国のモニタリングプロ グラムの紹介, 作物残留試験の方法と残留実態, 個別分析法な どの発表があった. E では, 輸出入に伴うモニタリングプログラ ムの紹介やマイナ一作物の読み替えなどに関する発表があっ た。

Residue に関するポスターの発表数は 200 題を超えており, 今回の ICPC で発表された総数 (約 1000 題強)の約 2 割を占め ていた.このため, Residueで発表された全ての報告を隈なく紹 介することは不可能であることから, 今回は, 3 名の担当者でそ れぞれ興味のあるテーマに限定して紹介することにした。

\section{多成分分析法（Subtopic A および B）}

多成分分析法は，農産物や食品の残留調査をはじめ環境調査 など多くの分野で必要としており，今回もそれらの分野におけ る報告が数多くあった (約 30 題). 方法としては，抽出成分を 各種 $\operatorname{SPE}(7 \mathrm{~A}-019,-020,-027,-032,-035,-040,-078)$ や GPC (7A-017，-027，-045，-046，7B-020) で精製した後，GC や LC で測定する方法が一般的であるが, 分析を必要とする農薬数と 試料数は年々増加しており, 更に簡便・迅速でしかも低コ、ト な分析法の必要性が高まってきている，このため，分析成分と 試料夾雑物の抽出効率をある程度制御することの可能な抽出装 置の活用 (SFE：7A-027，-044，7C-014)，精製法と測定装置と のオンライン化 (7A-020, 7B-001), 分析法の小規模・簡便化 (SPME 等：7A-031，-032，-037，-038，-039，-041)などの発表 が見られた.ただし，分析法が簡略化されるほど, 試料マトリッ クスによる測定誤差の問題が大きくなり，内標準法などの対応 が必要となってきている (7A-038,7B-002)。現在, GC で測定 可能な農薬については, 検出器として GC/MS を用いれば, ど のような農薬の組み合せであっても多成分分析法として構築す ることは概ね可能である.しかし，LCで測定する農薬について は，検出法も含めて分析法が多岐に瓦っていることもあり，未 だ統一的な方法として提示されていない. 近い将来, LC/MS(/ MS)の活用がこの問題の解決に大きく寄与するものと思われ る.

以下，個別の報告を幾つか紹介する.

SFE の応用例： $N$-メチルカーバメート系農薬は通常, ポス トカラム誘導体化 HPLC/FD で分析する方法が用いられてい るが, Anastassiades 等 (7A-044：Germany) は，果実および野
菜に残留する農薬をSFE で抽出し, 抽出成分をそのまま誘導体 化せずに LC/MS で測定した。 方法：試料 $3 \mathrm{~g}$ +脱水剂 $2 \mathrm{~g} \rightarrow$ SFE $($ HP-7680T) $\rightarrow$ LC/MS (API-ESI)。 8 種農薬 (Aminocarb, Bendiocarb, Carbanolate, Carbaryl, Carbofuran, Ethiofencarb, Methiocarb, Propoxur) のオレンジジュースからの回収は85〜 95\% $(\mathrm{RSD}=1.3 \sim 1.6 \%, n=5)$ で，極めて良好な結果を示した. 吉井等 (7A-027) は穀類に残留する農薬をSFE で抽出し, 多 孔性ケイソウ土と C18 の連結カラムで精製(脱脂)した後, GPC および Fl ミニカラムで精製し, HPLC, GC, GC/MS で測定し た。この方法により, 玄米, 小麦, 大麦に使用される大部分の 農薬を検出するが可能であった。

GC/MS の応用例：Anastassiades 等 (7B-002：Germany)は, 柑橘類に使用される農薬 50 種について, 体系的な分析法を構築 した. 本法の特徴として, (1)液液分配時の $\mathrm{pH}$ 調整により 2,4-D やCarbendazimのような誘導体化を必要とする農薬を分別し た. (2)液液分配の転溶溶媒に非塩素系溶媒（シクロへキサン+ 酢酸エチル)を使用した。 (3) GC/MS 測定に Matrix matched calibration を採用して測定誤差の最小化に努めた. (4)検出器と して GC/MS の一機種だけを使用した，などの点を上げてい る. 回収率は $0.5 \mathrm{ppm}$ レベルで 70〜 106\% (大部分の農薬成分は 80〜95\%) であった。

SPME の応用例：P. Viana 等 (7A-037：Portugal) は, 水中 の除草剂 6 種 (metalochlor, simazine, atrazine, propanil, alachlor, molinate) をSPME (polyacrylate) で抽出（捕集）し，直 接 $\mathrm{GC} / \mathrm{MS}$ で測定した. C18 (ディスクタイプ)による抽出効率 と比較して同程度であり，検量線も良好な直線性 $\left(\boldsymbol{r}^{2}=0.991\right.$ 0.999）を示した．水中濃度として 0.05 5 $\mu \mathrm{g} / l$ の範囲で測定可 能であったが, 夾雑物も同時に抽出されるため $\mathrm{GC} / \mathrm{MS}$ による 測定が不可欠であった。

M. Belmiloud 等（7A-038：UK）は, 地下水, 河川水, 飲料 水に含まれる農薬の分析に SPME (polyacrylate, polydimethylsiloxane)を応用した. 4 種農薬 (trifluralin, atrazine, isoproturon, linuron) を単独で抽出した場合と比較して, 混在状態で抽出し た場合は農薬によって回収が著しく低下寸る現象が見られた。 吸着能の低さが原因と推定され，このため夾雑物の共存が抽出 効率に影響を及ぼすことが予想されることから, SPME では標 準添加法の必要性が指摘された。 また，抽出時の試料状態とし て, A-静置, B-超音波振とう, C-マグネチックスターラー攪拌/ 中心部，D-マグネチックスターラー闃抖/中心外の 4 条件で比 較したところ，Dの条件が最大值を示した。

S. J. Crook 等 (7A-039 : UK) は, トリアゾール系農薬の作 物残留分析に SPME (polycarylate) を応用した。試料をアセ卜 ニトリル/水 $(35: 65)$ で抽出し, 抽出液の一部 $0.5 \mathrm{ml}$ (試料 0.1 $\mathrm{g}$ 相当) をサンプルビン（7 $\mathrm{ml}$ 容）に入れ，水を加えて $4 \mathrm{ml}$ と L, 以下, オンラインで SPME 抽出および GC/MS 測定を実施 した. $0.01 \sim 0.07 \mathrm{ppm}$ 程度の残留試料を用いて従来法と比較し たところ，分析值に大きな差は認められなかった。

\section{環境残留分析 (Subtopic C)}

環境に係わる残留や挙動を扱った報告が 49 題あり，それらの 内容は主に環境試料を対象とした分析法, モニタリングの方法 と結果, 環境挙動（運命）に区分することができる。 
環境試料を対象とした分析法 (20 題) では，土壤試料の抽出 方法に関する報告が多く見られ，SFE (7C-014，-027) や MAE （7C-048）を利用して土袞に吸着された農薬成分を効率よく抽 出する方法やカラムに土壌を充填して簡便に抽出する方法 (7C-003) 等が紹介された。検出方法としては, LC/MS (/MS) や GC/MS (/MS) などの機器分析の他に, 免疫化学的測定法 （IA）を利用した方法 (7C-007,-008，-009，-026，-034，-035） も見られ，特にIA 法は環境試料のモニタリングに積極的に利 用する意向が感じられる.

モニタリングの方法と結果 (4 題) では, 水 (河川水, 地下水, 飲料水), 土壤, 魚貝類, 大気, 生体試料等の調査結果が発表さ れ，相変わらず地下水で MRL $(0.1 \mathrm{ppb} / \mathrm{EU})$ 以上検出される農 薬が問題となっていた (7C-018). この他, 植物体 (葉) を分析 することにより大気中の農薬濃度をモニターする方法（7C050）などがあった.

環境挙動に係わる調查 (17 題) では, 土堙中での分解・移動・ 吸着, 大気への揮散, 圑場から河川への流出・移行等を扱った 報告が見られた。

この他, 深層の土堙試料を污染せずに採取する方法（7C025), 圃場での土壌残留試験における散布直後の土壌試料を捕 集材 (器) で代替する方法 (7C-049), 雨水に含まれる除草剂の 植物に対する NOEL を求め, 実際の雨水を評価した発表（7C038), 環境生物（鳥）の農薬暴露を調査するために鳥を傷つけ ることなく胃内容物を取り出し, 吐しゃ物中の農薬をIA 法で 測定した発表（7C-035）などがあった.

以下，個別の報告を幾つか紹介する。

土壤抽出法 (カラム)：J. L. Tadeo（7C-003：Spain）等は, 小規模化した土䇎の抽出方法を紹介した。土壌 $5 \mathrm{~g}$ をポリエチ レン製カラム $(20 \mathrm{ml}$ 容 $)$ に充填し, アセトン/水 $(9+1) 4 \mathrm{ml} \times$ 2 で抽出 (超音波槽内, $15 \mathrm{~min}$ ), $2 \mathrm{ml}$ で追加洗浄後, 抽出液を 合わせ，直接 GC/NPD および GC/MS で測定した. Simazine, thiazopyr, pendimethalin の回収 (0.2〜 1 ppmレベル) は96〜 103\%であり，従来法と比較してむしろ高い值を示した。

土壤抽出法(SFE)：R. Bossi 等 (7C-014：Denmark) は, 土䁃 中のスルホニルウレア系除草剂 (metsulfuron-methyl, chlorsulfuron, thifensulfuron-methyl, tribenuron-methyl）および底質中 の合成ピレスロイド系殺虫剂 (cypermethrin, fenpropathrin, esfenvalerate, permethrin, deltamethrin) の分析法として, SFEで 抽出した後, Sulfonylureas は直接LC/MS-ESI で, Pyrethroids は GC/ECD で測定した. SFEの Modifierとして,メタノール とアセトンを比較し, アセトンが有効であること, また, 含 $\mathrm{S}$ 化 合物などの共抽出物対策として，銅（粒）や硝酸銀の添加効果 を確認した。

モニタリング（水）：A. Balinova 等（7C-018：Bulgaria）は, 農耕地における地下水および河川水中の農薬濃度を調査（1995 ～96 年) し, 農薬使用や作物栽培の状況と比較した。 その結果, 河川水よりも地下水で高い濃度が検出されるケースが多く見ら れた. 河川水中の濃度は 6 7 月頃最高值に達し, 農薬散布時期 と関連があることから，農耕地からの表面流亡が原因と推定さ れた。地下水に抢いて検出頻度の高い農薬は atrazine (max 5.6 ppb), alachlor ( $\max 6.4$ ppb), 2,4-D の順であった. Fenitrothion,
$\mathrm{pp}^{\prime}$-DDT, $\mathrm{pp}$-DDE なども検出されたが，これらは基準値を大 きく下回っていた。

林等（7C-028）は, 水田で使用される農薬の一般河川への移 行を 1987 年から約 10 年間に瓦って調査した結果を報告した. 除草剂を主体とする 19 種農薬は C18 で抽出し, GC/MSまた は HPLCで測定した。CNP, Pretilachlor, Mefenacet, Molinate, Esprocarb, Simetryn, Bromobutide, Thiobencarb な゙の農薬が 検出されたが, 検出濃度はいずれも基準值を下回っていた. 河 川水中の濃度は農耕地における散布時期と相関があり, 一般に 散布後 10〜20日で最大に達した. また, 農薬の流出率と水溶解 度との間にも相関が認められ, 剂形とも関連があることを示唆 した.

土壤・作物残留：時枝等（7C-029）は，農耕地で使用される 農薬 (Acetamiprid) の土壌および作物における残留挙動を検討 するために，親化合物および親化合物と代謝物の共通構造を捉 えることのできる 2 通りの分析法を開発し, 多くの作物で圃場 試験を行った。 その結果, 作物中の主要残留物は親化合物だけ であった。また，コンテナおよび圃場土壤を用いた試験での土 壌中半減期は, 親化合物で $1 \sim 2$ 日, 代謝物を含む共通構造物と して15〜30日であった。

環境動態：I. R. Kennedy 等 (7C-033：Australia) は，固場に 散布された農薬 (Endosulfan) の挙動を調査し, 大部分は大気 中に揮散することを示した. 即ち, 散布後 30 日間で $71.2 \%$ 大 気中に，18.3\%が圃場内で分解， $8.2 \%$ 土壌中に残留， $1.8 \%$ が流 亡により消失,作物中には $0.5 \%$ 残留していた.土堙残留の主成 分は sulfate 体であり, この化合物の土壤中半減期が長いことが 原因であると推定した。なお，これらの調査デー夕は水系環境 への負荷を最小化するための圃場管理計画を策定する上で有用 であると結んでいる。

土壤溶出に係わる試験：P. Burauel 等 (7C-040：Germany) は, Benazolin-ethyl (新規剂) の土壤中での移動性を明らかにす るため, 室内試験およびライシメータ一試験を実施した。本報 告は標準的な試験法の一例と思われるので方法のみを記載す る. 室内試験：農薬処理土壤を 3 温度条件 $\left(6,15,25^{\circ} \mathrm{C}\right)$ およ び 3 土畩水分条件 $(20,40,60 \mathrm{WHC})$ で, 一定期間 $(0,2$, $6,11,25,39,91$ 日）培養した後, $0.01 \mathrm{M} \mathrm{CaCl}_{2}$, アセトン, 酢酸エチルで順次抽出し, 分析に供した.ライシメーター試験： $1 \mathrm{~m} \times 1 \mathrm{~m} \times$ 深さ $1.1 \mathrm{~m}$ (monoliths) のライシメーター4 基を用 い, 農薬の他に, 浸透特性をモニタ一するために $\mathrm{NaBr}$ を同時処 理した. 初めの一年間は非植生とし, 翌年からトウモロコシを 栽培した. 土壌試料は 6 力月および 14 力月後に 1 基のライシ メーターから採取し, 分析に供した。 土壌水分量と土堙温度の 測定は 2 基のライシメーターを用いて行った。

土壤吸着性：L. Madsen 等 (7C-041：Denmark) は, 有機物 含量の低い Aquifer sediments（地下水層土）の吸着要因につい て検討し, 地下水層土では有機物以外に $\mathrm{CaCO}_{3}$ が大きく関与 していることを示した. デンマーク国内から採取した 8 個所の 地下水層土を用いて, atrazine 等 6 種農薬の $K_{\mathrm{d}}$ 值を求めた. 方 法: 土壤 $5 \mathrm{~g}$ +水 $4 \mathrm{ml} \rightarrow 20$ 時間振とう $\rightarrow+{ }^{14} \mathrm{C}$-農薬/水 $1 \mathrm{ml}$ $\rightarrow(\mathrm{pH}$ 測定 $) \rightarrow 96$ 時間振とう $\rightarrow(\mathrm{pH}$ 測定 $) \rightarrow 3000 \mathrm{rpm}(20$ $\min ) \rightarrow$ 上清液 $\rightarrow$ LSC またはHPLC で測定. Atrazine, isoproturon, mecoprop, 2,4-Dの $K_{\mathrm{d}}=0.07 \sim 0.36$ であり, TOC から 
計算上求められる值と比較して, 高い吸着性を示した。供試土 の理化学的組成は $\mathrm{TOC}=0.07 \%, \mathrm{CaCO}_{3}=26.3 \%$, 粘土含量 $=<$ $0.1 \%$ あることから, 上記の結論に達した。

R. Ahmad 等 (7C-045: Australia) は, 土壤有機物含量と $K_{\mathrm{d}}$ との間の相関は小さい $\left(r^{2}=0.48 \sim 0.60\right)$ が, 土䁃有機物中の aromaticity $\left({ }^{13} \mathrm{C}-\mathrm{CP} / \mathrm{MAS}-\mathrm{NMR}\right.$ で計測）との間には高い相関 $\left(r^{2}=0.99\right)$ があることを, carbaryl の土袞吸着性試験（14 種土 㙵使用）から明らかにし, 走查電子顕微鏡で結合状態を調査し た. 